\title{
The Ragged Edge of Anarchy: Direct Democracy
}

\author{
John Asimakopoulos ${ }^{1}$
}

The paper argues anarchism is synonymous with direct democracy and explores ways of implementing such a system in practical terms without the destruction of the existing system. Many utopians either envision a slow evolutionary transformation of society or an abrupt revolutionary break with existing systems. I argue that both can be achieved simultaneously by selecting personnel for positions of authority in political and economic institutions via lottery. Such changes would not destroy what is overnight only to replace it with a possibly worse nightmare than what preceded it. Yet, the changes proposed here would usher in a new era centered on citizens, not elites, horizontal rather than hierarchical social relations. [Article copies available for a fee from The Transformative Studies Institute. E-mail address: journal@transformativestudies.org Website: http://www.transformativestudies.org (C2020 by The Transformative Studies Institute. All rights reserved.]

KEYWORDS: Direct Democracy, Anarchy, Critical Theory.

Athenian democracy in classical Greece is considered the epitome of a political structure where the demos actually ruled. Of course, there was the caveat of who qualified as a citizen. Slaves, immigrants, and women were excluded from public life. The fundamental tenet of direct democracy is that every citizen comprising the demos or community 'represents' themselves as sovereigns in decision-making, meaning in Greek that they are autonomos (self-legislating), autodikos (selfjudging), and autoteles (self-governing). They did not vote for someone to vote for them. The political unit, therefore, for Greeks was not the 'State' (a word that did not exist), but the polis (city, meaning the

\footnotetext{
${ }^{1}$ John Asimakopoulos, Ph.D., is Full Professor of Sociology at the City University of New York. His research focusses on social movements, critical theory, and international political economy. Asimakopoulos is author of The Political Economy of the Spectacle and Postmodern Caste (2020), Against Capital in the Twenty-First Century (2018), Social Structures of Direct Democracy (2016), The Accumulation of Freedom (2012), Revolt! (2011), and many journal articles. Address correspondence to: John Asimakopoulos, e-mail: jasimakopoulos@transformativestudies.org.
} 